${ }^{4}$ Haber, I, and Hubens, H, Tijdschrift voor Gastro-Enterologie, 1976, 19, 316.

5 Allan, R, and Dykes, P, Gastrointestinal Endoscopy, 1974, 20, 154.

${ }^{6}$ British Medical Fournal, 1974, 1, 403.

Stevenson, G W, Cox, R R, and Roberts, C J C, British Medical fournal, 1976, 2, 723.

${ }^{\gamma}$ McGinn, F P, et al, Gut, 1975, 16, 707

${ }^{9}$ Hellers, G, and Ihre, T, Lancet, 1975, 2, 1250

10 Allen, H M, Block, M A, and Schuman, B M, Archives of Surgery, 1973, 106, 450 .

${ }^{11}$ Keller, R T, and Logan, G M, jun, Gut, 1976, 17, 180.

12 Myren, J, Scandinavian fournal of Gastroenterology, 1971, suppl No 9, p 67.

3 Dronfield, M w, et al, Lancet, 1977, 1, 1167

14 Hoare, A M, British Medical fournal, 1975, 1, 27.

15 Forrest, J A H, Finlayson, N D C, and Schearman, D J C, Lancet, 1974, 2,394 .

16 Porro, G B, and Petrillo, M, Lancet, 1975, 1, 110.

17 Leinicke, J A, et al, Gastrointestinal Endoscopy, 1976, 22, 228

${ }^{18}$ Fraenkel, G J, and Truelove, S C, British Medical fournal, 1955, 1, 999.

19 Schiller, K F R, Truelove, S C, and Williams, D G, British Medical fournal, 1970, 2, 7 .

3" Johnston, S J, et al, British Medical fournal, 1973, 3, 655.

21 Avery Jones, F, Gastroenterology, 1956, 30, 166.

22 Jones, P F, et al, British Medical fournal, 1973, 3, 660

23 Northfield, T C, British Medical fournal, 1971, 1, 26.
${ }^{24}$ Swinscow, T D V, British Medical fournal, 1976, 2, 513.

${ }^{25}$ Morgan, A G, et al, British Medical fournal, 1977, 2, 237.

${ }^{26}$ Forrest, J A H, and Logan, R F A, British Medical fournal, 1977, 1, 50.

27 Sandlow, L J, et al, American fournal of Gastroenterology, 1974, 61, 282.

${ }^{28}$ Cammock, E E, et al, Archives of Surgery, 1963, 86, 608.

${ }^{29}$ Andersen, D, Klebe, J G, and Nielsen, A, Scandinavian fournal of Gastroenterology, 1968, 3, 537.

30 Khodadoost, J, and Glass, G B J, Digestion, 1972, 7, 129.

${ }^{31}$ Crook, J N, et al, Annals of Surgery, 1972, 175, 771.

${ }^{32}$ Hegarty, M M, Grime, R T, and Schofield, F, British fournal of Surgery, 1973, 60, 275

${ }^{33}$ Foster, D N, Miloszewski, K J A, and Losowsky, M S, Lancet, 1976, 2, 483

${ }^{34}$ Katz, D, et al, American fournal of Digestive Diseases, 1976, 21, 182.

35 Waldram, R, et al, British Medical fournal, 1974, 4, 94.

${ }^{36}$ McCray, R S, et al, American fournal of Digestive Diseases, 1969, 14, 755.

37 Bonanno, C A, Robilotti, J G, jun, and Martel, A J, Gastroenterology, 1972, 62, 883 .

${ }^{38}$ Cotton, P B, British Medical fournal, 1976, 2, 1197.

${ }^{39}$ Walls, W D, Glanville, J N, and Chandler, G N, Lancet, 1971, 2, 387.

"Allan, R, and Dykes, P, Quarterly fournal of Medicine, 1976, 45, 533.

11 Axon, A T R, and Clarke, A, British Medical fournal, 1975, 1, 491.

\title{
Pituitary-testicular interrelationships in mumps orchitis and other viral infections
}

\author{
D A ADAMOPOULOS, D M LAWRENCE, P VASSILOPOULOS, P A CONTOYIANNIS, \\ G I M SWYER
}

British Medical fournal, 1978, 1, 1177-1180

\section{Summary and conclusions}

Leydig-cell function was assessed in 27 men with acute mumps orchitis by measuring plasma testosterone concentrations before and after the administration of human chorionic gonadotrophin (HCG). The test was also performed on groups of patients with other febrile viral infections and mumps without orchitis and on healthy euspermic men. The concentrations both before and after HCG were significantly lower in patients in the acute phase of mumps-but not in those with other viral infections and mumps without orchitis-than in the healthy men. Basal concentrations of follicle-stimulating hormone (FSH) and luteinising hormone (LH) were significantly increased in patients with acute mumps orchitis, while an exaggerated response to LH-releasing hormone was noted in four patients after the acute phase of the disease. Raised plasma LH concentrations were also found in several patients with viral infections, including mumps without orchitis. There appeared to be no particular merit of any of the treatments used

Endocrine Clinic, “M Eliadi” Hospital, Athens 601, Greece

D A ADAMOPOULOS, DM, consultant endocrinologist

P VASSILOPOULOS, DM, research associate

Endocrine Research Laboratory, University College Hospital Medical School, London WC1E 6DH

D M LAWRENCE, PHD, senior biochemist

G I M SWYER, FRCP, consultant endocrinologist

Hospital for Infectious Diseases, Athens, Greece

P A CONTOYIANNIS, DM, consultant physician (aspirin, prednisolone, and cold baths). In patients reevaluated three to five and 10 to 12 months after the acute phase of their disease the basal testosterone concentrations were similar to those of the healthy men, but several of the patients showed a severely impaired response to HCG. Mean basal FSH and LH concentrations were significantly increased 10 to 12 months after the acute phase, while the mean $L H$ concentration was also raised at three to five months.

It is concluded that mumps orchitis impairs Leydigcell function during the acute phase of the disease but may also have a more permanent damaging effect, similar to that found in the germinal epithelium.

\section{Introduction}

Orchitis is the commonest complication of mumps in postpubertal boys and men and develops in $15-25^{\circ}{ }_{0}$ of patients. Variable degrees of germinal epithelial atrophy occur in half the cases, but since bilateral disease is seen in only $20-25^{\circ}$ of the patients affected ${ }^{12}$ sterility is less common. Though the consequences of mumps orchitis on the tubular system of the testis are well known, ${ }^{3}$ Leydig-cell function during the acute phase and after recovery from the disease has not been documented. We therefore report the results of an assessment of Leydig-cell function, as judged by basal testosterone secretion and its response to human chorionic gonadotrophin (HCG), in patients with mumps orchitis, mumps without orchitis, and other febrile viral infections. Pituitary gonadotrophins were also evaluated, in most cases by measuring basal concentrations of follicle-stimulating hormone $(\mathrm{FSH})$ and luteinising hormone (LH), and in a few by means of an LH-releasing hormone (LH-RH) stimulation test. The effect of the different therapeutic regimens employed in the acute phase of mumps orchitis was also examined. A preliminary account of this study has been given. ${ }^{4}$ 


\section{Subjects and methods}

Sixty-one men were included in the study, all of whom gave informed consent. Thirty-four served as controls, and 27 were patients with mumps orchitis.

Controls-The control group comprised 17 healthy euspermic men; eight patients with febrile viral infections other than mumps (six with measles, two with chickenpox); and nine patients with mumps without orchitis.

Patients with mumps orchitis-Of the 27 patients with orchitis, 11 had unilateral disease and 16 bilateral disease. All were investigated during the acute phase of their disease, and 12 agreed to take part in the follow-up study. Of these, 10 were re-evaluated three to five months later and eight 10 to 12 months later (early and late recovery phases). During the acute phase the patients were allocated at random to treatment with local cold baths (nine patients), aspirin $3 \mathrm{~g}$ daily (nine), or prednisolone $30 \mathrm{mg}$ daily (nine) for four to seven days.

The mean age of the healthy men was $36 \cdot 6 \pm$ SD $5 \cdot 9$ years and of the patients $29.9 \pm 10.9$ years. No evidence of systemic or endocrine disease was noted in any of the subjects studied, and none had been receiving medication before the study. Some of the patients without orchitis were given aspirin or its analogues for fever until they were normothermic. The healthy men were defined as euspermic on the basis of two recent semen analyses. Semen analysis was not performed on any of the patients immediately after the acute phase of their disease. Of the 16 married men with orchitis, however, 13 had fathered at least one child.

A Leydig-cell stimulation test was performed by giving $1500 \mathrm{IU}$ of HCG (Pregnyl) every 48 hours intramuscularly three times and sampling before and 24 hours after the last injection. Pituitary gonadotrophic function was assessed with an LH-RH test $(100: \mathrm{kg}$ given intravenously) in eight of the euspermic men, three patients during the acute phase of mumps orchitis, and in one of these three months later.

Basal FSH and LH estimations were performed on most of the men in the control and orchitis groups. Blood was drawn between 0800 and 1000 , and plasma was kept at $-20^{\circ} \mathrm{C}$ until assayed.

Plasma testosterone was assayed by radioimmunoassay without chromatography as described by Castro et al..$^{5}$ In our hands sensitivity and specificity were similar to those found by Castro et al, and we obtained similar normal ranges. The coefficient of interassay variation for a concentration of $22.88 \pm S D 1.97 \mathrm{nmol} / 1(6.60 \pm 0.57 \mathrm{ng} / \mathrm{ml})$ was $8 \cdot 6(\mathrm{n}=19)$, and for a concentration of $12.68 \pm 1 \cdot 07 \mathrm{nmol} / 1(3.66 \pm 0.31$ $\mathrm{ng} / \mathrm{ml}) 7 \cdot 1=(\mathrm{n} \mathrm{9})$. Gonadotrophin estimations were performed with commercially available assay systems (kit Cea-Ire, Sorin) employing a double-antibody technique. In these systems $1 \mathrm{mg}$ of the standard preparation used has radioimmunological activity equal to $2830+320$ IU 68/39 MRC for FSH, and 2160 \pm 240 IU $68 / 40 \mathrm{MRC}$ for $\mathrm{LH}$

\section{Results}

Figure 1 shows the individual changes in plasma testosterone concentrations after HCG administration during the acute phase of orchitis and in patients with other viral infections and mumps without orchitis. In 19 of the 27 patients with orchitis basal values were below the lower end of the range for healthy men, while in six of the remainder the values were close to the lower end of the range. In contrast, all of the patients with viral infections and mumps without testicular disease had values within the healthy men's range both before and after HCG. The mean plasma testosterone concentrations before and after stimulation with HCG in the groups studied are shown in table I. Wide variations in individual and mean values were found. Use of Dunnett's multiple comparison procedure ${ }^{i}$ showed that the mean basal and post-HCG testosterone concentrations in the patients with acute orchitis were significantly lower than those of the healthy men. Such a difference was not seen between the healthy subjects and patients with viral infections or mumps without orchitis.

Table II shows the basal FSH and LH concentrations in the groups studied. A raised FSH concentration was found in 11 patients with acute-phase orchitis and in one with a viral infection other than mumps. The plasma LH concentration was raised in 10 patients with acute-phase orchitis, three with viral infections other than mumps, and two with mumps without orchitis. The mean FSH and LH concentrations in the acute-orchitis and late-recovery groups were significantly higher than those of the healthy men, whereas in the early-recovery group only the mean $\mathrm{LH}$ concentration was significantly raised. On the other hand, the patients with other viral infections and mumps without orchitis had normal FSH concentrations, the LH concentration being significantly increased only in the group with viral infections.

Analysis of the results in terms of the treatment used and whether one or both testes were affected showed that the mean plasma testosterone concentrations before and after HCG were significantly lower than that of the healthy men in all but the patients given the cold-bath treatment and those with unilateral disease. Cold-bath treatment was mainly given to patients with unilateral orchitis, and in these the post-HCG values did not differ from that of the healthy men. Furthermore, in the same subgroups the mean FSH concentrations were similar to that of the healthy men, whereas in the remaining subgroups significantly increased concentrations were found. LH concentrations

TABLE I-Plasma testosterone concentrations before and after administration of HCG

\begin{tabular}{|c|c|c|c|c|c|c|c|c|c|}
\hline & & \multicolumn{4}{|c|}{ Before HCG $(\mathrm{nmol} / \mathrm{l})$} & \multicolumn{4}{|c|}{ After HCG $(\mathrm{nmol} \mathrm{l})$} \\
\hline & & Mean + SD & Range & $\begin{array}{c}\text { No of } \\
\text { observations }\end{array}$ & $\begin{array}{c}\text { Difference } \\
\text { from healthy } \\
\text { men }\end{array}$ & Mean : SD & Range & $\begin{array}{c}\text { No of } \\
\text { observations }\end{array}$ & $\begin{array}{c}\text { Difference } \\
\text { from healthy } \\
\text { men }\end{array}$ \\
\hline 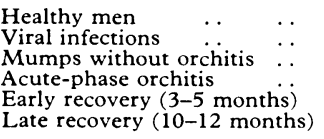 & $\begin{array}{l}\cdots \\
\cdots \\
\cdots \\
\cdots\end{array}$ & 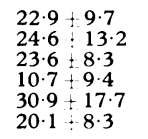 & $\begin{array}{c}13 \cdot 5-53 \cdot 4 \\
13 \cdot 5-53 \cdot 0 \\
14 \cdot 2-37 \cdot 4 \\
0 \cdot 3-37 \cdot 4 \\
6 \cdot 9-65 \cdot 9 \\
10 \cdot 1-31 \cdot 2\end{array}$ & $\begin{array}{r}17 \\
8 \\
9 \\
27 \\
10 \\
8\end{array}$ & $\begin{array}{l}\text { NS } \\
\text { NS } \\
\text { S }^{*} \\
\text { NS } \\
\text { NS }\end{array}$ & 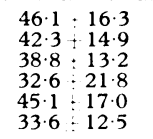 & $\begin{array}{l}25 \cdot 3-86 \cdot 7 \\
28 \cdot 8-87 \cdot 0 \\
27 \cdot 7-69 \cdot 7 \\
2 \cdot 1-114 \cdot 4 \\
13 \cdot 2-68 \cdot 6 \\
15 \cdot 3-55 \cdot 1\end{array}$ & $\begin{array}{r}17 \\
8 \\
9 \\
27 \\
10 \\
8\end{array}$ & $\begin{array}{l}\text { NS } \\
\text { NS } \\
\text { S+ } \\
\text { NS } \\
\text { NS }\end{array}$ \\
\hline
\end{tabular}

*Two-sided for $\mathrm{P}=99^{\circ}$

+One-sided for $\mathrm{P}=95^{\circ}$

S $=$ Si gnifican

Conversion: SI to traditional unit:-Plasma testosterone: $1 \mathrm{nmol} / 1 \approx 0.29 \mathrm{ng} / \mathrm{ml}$

TABLE II-Basal plasma FSH and $L H$ concentrations

\begin{tabular}{|c|c|c|c|c|c|c|c|c|c|}
\hline & & \multicolumn{4}{|c|}{ Basal FSH concentrations $(\mu \mathrm{g} / \mathrm{l})$} & \multicolumn{4}{|c|}{ Basal LH concentrations $(\mu \mathrm{g} / 1)$} \\
\hline & & Mean + SD & Range & $\begin{array}{c}\text { No of } \\
\text { observations }\end{array}$ & $\begin{array}{c}\text { Difference } \\
\text { from healthy } \\
\text { men }\end{array}$ & Mean $+\mathrm{SD}$ & Range & $\begin{array}{c}\text { No of } \\
\text { observations }\end{array}$ & $\begin{array}{l}\text { Difference } \\
\text { from healthy } \\
\text { men }\end{array}$ \\
\hline 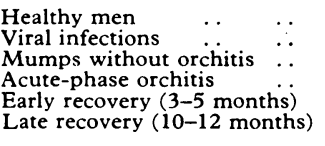 & $\begin{array}{l}\cdots \\
\cdots \\
\cdots \\
\cdots \\
\cdots\end{array}$ & $\begin{array}{l}2 \cdot 0 \pm 1 \cdot 0 \\
2 \cdot 2+2 \cdot 2 \\
1 \cdot 4 \pm 1 \cdot 3 \\
3 \cdot 7 \pm 2 \cdot 6 \\
5 \cdot 5 \pm 4 \cdot 3 \\
4 \cdot 1 \pm 1 \cdot 6\end{array}$ & $\begin{array}{l}0 \cdot 5-3 \cdot 8 \\
0 \cdot 5-6 \cdot 4 \\
0 \cdot 5-3 \cdot 7 \\
0 \cdot 9-10 \cdot 9 \\
1 \cdot 4-16 \cdot 0 \\
1 \cdot 4-5 \cdot 8\end{array}$ & $\begin{array}{r}13 \\
6 \\
6 \\
22 \\
7 \\
6\end{array}$ & $\begin{array}{l}\text { NS } \\
\text { NS } \\
S^{*} \\
\text { NS } \\
S^{*}\end{array}$ & $\begin{array}{rl}3 \cdot 6 & +1 \cdot 8 \\
8 \cdot 6 & 3 \cdot 9 \\
8 \cdot 1 & 6 \cdot 5 \\
8 \cdot 3 & +5 \cdot 7 \\
12 \cdot 9 & 8 \cdot 1 \\
8 \cdot 7 & -3 \cdot 7\end{array}$ & $\begin{array}{l}1 \cdot 7-7 \cdot 4 \\
4 \cdot 3-14 \cdot 0 \\
1 \cdot 9-19 \cdot 0 \\
2 \cdot 9-26 \cdot 1 \\
3 \cdot 9-29 \cdot 0 \\
4 \cdot 6-19 \cdot 6\end{array}$ & $\begin{array}{r}13 \\
6 \\
6 \\
22 \\
7 \\
6\end{array}$ & $\begin{array}{l}\mathrm{S}^{*} \\
\mathrm{NS}^{+} \\
\mathrm{S}^{+} \\
\mathbf{S}^{*} \\
\mathrm{~S}_{+}^{+}\end{array}$ \\
\hline
\end{tabular}

*Two-sided for $P=0.05$

TTwo-sided for $P=0.01$

$P=0.01$.

NS = Not significant. $\quad \dot{S}=$ Significant. 
were significantly increased irrespective of the type of treatment used or whether the disease was unilateral or bilateral.

Figure 2 shows the response to $\mathrm{HCG}$ in the 12 patients studied serially. Two patients (cases 3 and 4 ) and four patients (cases 9 to 12) were not tested at three to five and 10 to 12 months respectively. A pronounced increase in basal testosterone concentrations and response to HCG was noted from the acute to recovery phases in a few patients (cases 8, 9, 10, and 11), but in most no change (cases 2 and 7), a decreased response or low basal values or both (cases 1, 3, 4, and 5), and a negative response (cases 6 and 12) were noted. At the same time raised gonadotrophin concentrations were seen in several patients. The

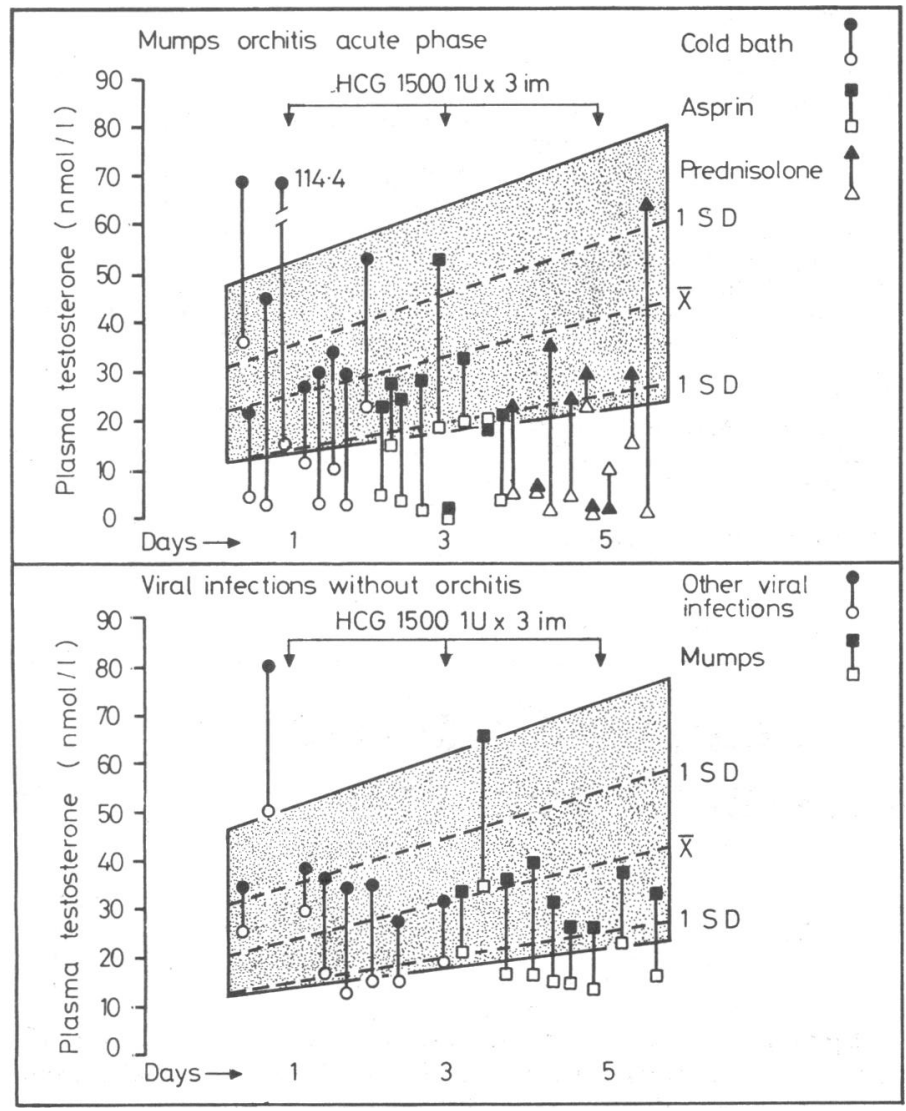

FIG 1-Individual plasma testosterone concentrations before (open symbols) and after (closed symbols) intramuscular HCG in patients with mumps orchitis during acute phase and in patients with other viral infections and mumps without orchitis. Shaded areas are healthy men's range of responses.

Conversion: SI to traditional units-Plasma testosterone: $1 \mathrm{nmol} / 1=0.29$ $\mathrm{ng} \mathrm{ml}$.

mean acute-phase values (for recovery-phase values, see table I) were as follows: testosterone, basal $9 \cdot 0 \pm \mathrm{SD} 8 \cdot 0 \mathrm{nmol} / 1(2 \cdot 6 \pm 2 \cdot 3 \mathrm{ng} / \mathrm{ml})$, after HCG $43.7 \pm 27.7 \mathrm{nmol} / 1 \quad(12.6 \pm 8.0 \mathrm{ng} / \mathrm{ml}) \quad(\mathrm{n}=12) ; \mathrm{FSH}$ $3.9 \pm 3 \cdot 0<\mathrm{g} / \mathrm{l}, \mathrm{LH} 8 \cdot 6 \pm 4 \cdot 3 \mathrm{~kg} / \mathrm{l}(\mathrm{n}=10)$. The mean basal testosterone concentration in the acute phase in the serially studied group was significantly lower than that of the healthy men $(P=0.01)$, while the mean values for the recovery phases were not significantly different from that value. The post-HCG concentrations in the acute, early, and late recovery phases were not significantly different from that of the healthy men, despite the presence of several poor responders with low basal values, particularly in the late-recovery group. No significant difference in mean FSH and LH values was found between the three phases. All the values were significantly higher than the corresponding ones for the healthy men with the exception of FSH in the acute phase.

The mean responses to $\mathrm{LH}-\mathrm{RH}$ in the eight euspermic men were: FSH, basal $2.4 \pm 0.8 \mathrm{~kg} /$, at $30 \mathrm{~min} 6.5 \pm 2 \cdot 1 \mathrm{~kg} / \mathrm{l}$, and at $60 \mathrm{~min}$ $8 \cdot 1 \pm 2 \cdot 4 \mathrm{\mu g} / \mathrm{l}$; and $\mathrm{LH}$, basal $4.0 \pm 1 \cdot 0 \mathrm{~kg} / \mathrm{l}$, at $30 \mathrm{~min} 36 \cdot 9 \pm 6 \cdot 3 \mathrm{\mu g} / \mathrm{l}$, and at $60 \mathrm{~min} 30.5 \pm 4.9 \mathrm{~kg} / 1$. In contrast, four patients with bilateral orchitis studied immediately after the acute phase (three patients) and three months later (one) showed both higher basal values and exaggerated responses to $\mathrm{LH}-\mathrm{RH}$ (fig 3).
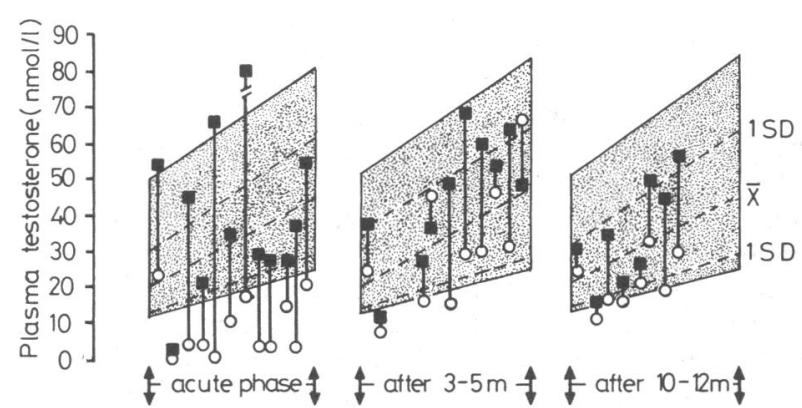

$f$ after $3-5 m \neq \neq$ atter $10-12 m f$

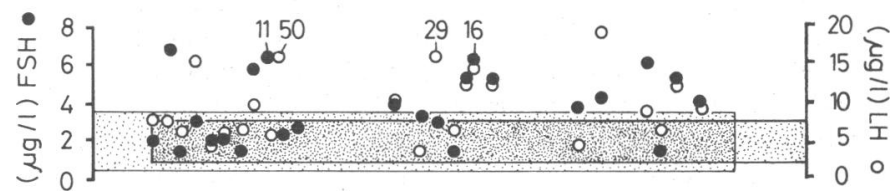

FIG 2-Top: Individual plasma testosterone concentrations before (open symbols) and after (closed symbols) intramuscular HCG in 12 patients with mumps orchitis studied serially. Bottom: Individual basal FSH and $\mathrm{LH}$ concentrations in patients with orchitis studied serially. Shaded areas are healthy men's range of responses. The points from left to right represent patients enumerated 1 to 12 . Some patients could not be evaluated at three to five and 10 to 12 months.

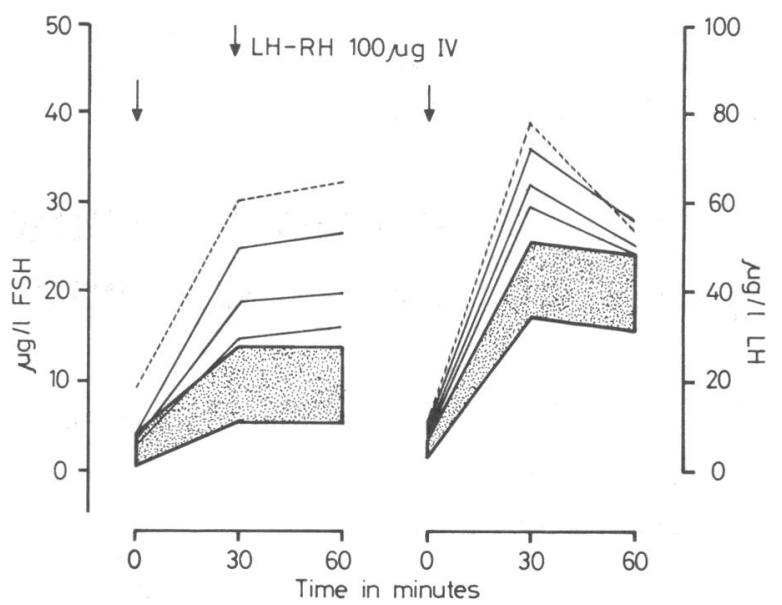

FIG 3-Responses of FSH and $\mathrm{LH}$ to intravenous $\mathrm{LH}-\mathrm{RH}$ in eight euspermic men (shaded areas), three patients immediately after acute phase of bilateral orchitis (solid lines), and in one patient three months after acute phase of bilateral orchitis (broken lines).

\section{Discussion}

These results show that Leydig-cell function, as judged by plasma testosterone concentrations, both under basal conditions and after stimulation, was impaired in patients with acute orchitis. Most patients showed a strong response to HCG, though the mean post-HCG value was lower than that found in healthy men. In contrast, no significant deviations from normal values were found in patients suffering from other viral infections or mumps without orchitis. The evidence for reduced testosterone secretion in acute orchitis was further supported by the finding of raised basal $\mathrm{LH}$ concentrations and exaggerated responses to $\mathrm{LH}-\mathrm{RH}$.

Interestingly, $\mathrm{LH}$ concentrations were also increased in some patients with viral infections who had no evidence of testicular dysfunction. Stresses such as exercise, anaesthesia, and surgery ${ }^{7} \&$ have been associated with an increase in $\mathrm{LH}$ secretion, concomitant in patients undergoing surgery with a decline in testosterone. On the other hand, an increase in plasma or urinary LH concentrations in association with normal testosterone values is well recognised in hypogonadal states ${ }^{910}$ and was often observed in the serially studied patients, who also 
showed a satisfactory response to HCG. Whether this occurred as a compensatory adjustment of the "gonadostat" necessary for maintaining adequate testosterone secretion or as a nonspecific effect of the prevailing general conditions on pituitary gonadotrophic function remains a matter of speculation.

Low basal and post-HCG testosterone concentrations and a subnormal response to HCG, particularly in the late recovery phase, indicated that impairment of Leydig-cell function may have occurred in several patients as a result of mumps orchitis. The condition probably develops as a long-term effect of the disease, leading to permanent damage of the Leydig cells similar in importance to that of the germinal epithelium.

Satisfactory post-HCG testosterone and basal FSH concentrations were found in patients with acute unilateral orchitis and those treated with cold baths. Probably in patients with unilateral disease a large proportion of the Leydig-cell population, notably that of the unaffected testis, functioned properly to sustain testosterone secretion within the normal range. Cold bathing may also have had some protective effect, though no firm conclusion on its efficacy as a therapeutic regimen could be drawn.

Though we expected the plasma FSH concentration to be increased in patients with mumps orchitis, we were surprised that it occurred at such an early stage. After recovery the FSH concentrations, and LH concentrations, remained high in some patients.

Our findings show that mumps orchitis has a deleterious effect on Leydig cells in the acute phase of the disease and may result in permanent impairment of their secretory activity. The long-held view that Leydig-cell function is preserved more or less intact after recovery from mumps orchitis should therefore be reconsidered.

We express our gratitude to the patients and healthy subjects who participated in this study. The work was partly supported by a grant from "Empirikeion Foundation" to DAA. LH-RH was donated by Hoechst AG.

Requests for reprints should be sent to DAA.

\section{References}

1 Marcy, S X, and Kibrick, S, Infectious Diseases, p 657. New York, Harper and Row, 1972.

2 Top, F H, and Wehrle, P F, Communicable and Infectious Diseases, p 427. St Louis, C V Mosby, 1972.

3 Turner, J H, and Bloodworth, J M B, Endocrine Pathology, ed J M B Bloodworth, p 430. Baltimore, Williams and Wilkins, 1968.

+ Adamopoulos, D A, et al, Acta Endocrinologica (Kфbenhavn), 1975, 199, suppl, p 416 (abstract).

5 Castro, A, Shih, H H W, and Chung, A, Steroids, 1974, 23, 625.

${ }_{6}$ Dunnett, C W, American Statistical Association fournal, 1955, 50, 1096

Sowers, R A J, jun, et al, Acta Endocrinologica (Kфbenhavn), 1977, 86, 25.

"Aono, T, et al, fournal of Clinical Endocrinology and Metabolism, 1976, 42, 144.

9 Paulsen, C A, et al, Recent Progress in Hormone Research, 1968, 24, 321.

10 Adamopoulos, D A, et al, fournal of Reproduction and Fertility, 1971, 25, 409.

(Accepted 27 February 1978)

\title{
Underlying immunopathology as a cause of adverse responses to two intravenous anaesthetic agents
}

\author{
JOHN WATKINS, ADRIAN PADFIELD, J D ALDERSON
}

British Medical fournal, 1978, 1, 1180-1181

\section{Summary and conclusions}

A patient who had shown some evidence of immunological sensitivity underwent several operations under general anaesthesia for otitis media without ill effect. On his second exposure to Althesin, however, he suffered a severe reaction. Facial angioneurotic oedema was accompanied by peripheral vasodilatation and sweating, and C3 conversion was observed in his plasma. Subsequent anaesthetics produced no reactions until four years later, when thiopentone and suxamethonium were given. This reaction was much milder, but $\mathrm{C} 3$ conversion again occurred. Although the clinical signs indicated an anaphylactoid reaction, the laboratory findings suggested that this patient had an underlying immunopathological condition involving complement activation, which could be triggered by any intravenous agent that activated complement.

The judgment that a reaction to a particular drug is

\footnotetext{
University of Sheffield Medical School, Hallamshire Hospital, Sheffield S10 2RX

JOHN WATKINS, PHD, principal scientific officer, department of immunology

ADRIAN PADFIELD, MB, FFARCS, consultant anaesthetist

J D ALDERSON, MB, FFARCS(I), senior registrar in anaesthetics
}

anaphylactic cannot be made on the basis of clinical signs alone. Simple laboratory analysis will show whether the reaction is due to an underlying immunopathological condition that may be triggered by any of several drugs.

\section{Introduction}

There is now considerable interest in the incidence and mechanism of adverse responses (either histaminoid or anaphylactoid) to intravenous agents. We describe here a patient who responded adversely to two intravenous anaesthetic agents which were administered on separate occasions for identical operations.

\section{Case report}

A 21-year-old student had suffered from otitis media since infancy, for which he had undergone several operations under genera anaesthesia over the past 12 years (table I). He showed some evidence of immunological hypersensitivity in that he had developed eczema in infancy and was noted by his parents to be sensitive to orange juice, which gave him swollen lips. Skin tests were unable to confirm this allergy to orange juice.

His first exposure to Althesin (alphaxalone and alphadolone acetate), in 1973, was uneventful, but his second, for an identical procedure about 18 months later, produced dramatic effects. Anaesthesia was induced intravenously with $4.5 \mathrm{ml}$ of Althesin, and three minutes later angioneurotic oedema developed around the lips and spread across the face. This was accompanied by peripheral vasodilatation and sweating. There was no bronchospasm, dyspnoea, or cyanosis but the pulse 